\title{
No reliable evidence for a very early Aurignacian in Southern Iberia
}

To the Editor - Cortés-Sánchez et al. ${ }^{1}$ presented a series of radiocarbon dates and an associated Bayesian model for the Palaeolithic site of Bajondillo (Málaga, Spain). Their study focuses on level $\mathrm{Bj} / 13$, which, on the basis of its lithic assemblage, they attribute to the Aurignacian and hence to anatomically modern humans (AMHs) ${ }^{2}$. They find that $B j / 13$ dates to approximately 43.0-40.8 calibrated thousand years before the present (cal ka BP) and, therefore, that AMH were present in southern Iberia thousands of years earlier than previously suggested. However, there are several shortcomings in their data and chain of reasoning, which relies on two propositions: (1) $B j / 13$ is homogeneous and unmixed and (2) $\mathrm{Bj} / 13$ can be confidently attributed to the Aurignacian.

In previous publications, the same team has stated that it is 'extremely difficult' to determine a chrono-cultural attribution for ' $\mathrm{Bj} / 13-12^{\prime 3}$, describing it as 'Middle Palaeolithic/Upper Palaeolithic', 'Middle Palaeolithic?'? and as a likely mix of Mousterian with Aurignacian or a generalized Upper Palaeolithic component ${ }^{5}$. Solifluction was identified at the irregular $\mathrm{Bj} / 11$ and $\mathrm{Bj} / 13-12$ contact ${ }^{4,5}$, and levels $\mathrm{Bj} / 14-11$ were excluded from a previous dating project owing to suspected mixing between layers ${ }^{6}$. Moreover, according to Supplementary Fig. 1 (ref. ${ }^{1}$ ), Bj/13 was present only in a limited part of the site's central section, and it was in contact with both underlying Mousterian and overlying Evolved Aurignacian layers. Their new interpretation of $B j / 13$ as unmixed Aurignacian is presented without explanation. No results from new taphonomic studies, such as interlevel lithic refits or sedimentary analyses, are provided to corroborate the integrity of the layer and its assemblage. The assemblage may contain a blade/bladelet component, but it also has a strong flake component; mixing needs to be ruled out as a possible cause for any technotypological similarities between $\mathrm{Bj} / 13$ and stratigraphically higher Aurignacian layers.

In any case, the attribution of the $\mathrm{Bj} / 13$ assemblage to the Aurignacian appears to be unfounded. No described features of the lithics, either retouched $(n=10)$ or unretouched $(n=343)$, are diagnostically Aurignacian ${ }^{7}$. The 'flat nosed end-scraper' (object no. 1 in Bj/13 section of Fig. 2 in ref. $\left.{ }^{1}\right)$ lacks the technological features of Aurignacian 'nosed scrapers', which are actually carinated bladelet cores ${ }^{8,9}$ (for example, object nos. 1 and 3 in $\mathrm{Bj} / 11$ section of Fig. 2 in ref. ${ }^{1}$ ). Unlike the true (nonbladelet core) end-scrapers from $\mathrm{Bj} / 11$ (object nos. 2, 5 and 8 in $\mathrm{Bj} / 11$ section of Fig. 2 in ref. ${ }^{1}$ ), it is made on a flake, rather than a blade. The $\mathrm{Bj} / 13$ flat nosed endscraper in fact appears similar to retouched flakes found in many Middle and Upper Palaeolithic assemblages; there is no reason to describe it as Aurignacian or link it with the Aurignacian artefacts from $\mathrm{Bj} / 11$. Furthermore, the description of increased blade/bladelet numbers and associated maintenance flakes in $\mathrm{Bj} / 13$ compared with $\mathrm{Bj} / 14$ is inconclusive in regard to an attribution to the Aurignacian.

It is inappropriate to describe a layer as Aurignacian based simply on the presence of a potential blade/bladelet component and a stratigraphic position between Middle Palaeolithic and Evolved Aurignacian levels. The attribution of an assemblage to the Proto-Aurignacian or Early Aurignacian must be based on the presence of particular techno-typological features from the Aurignacian technocomplex sensu lato, regardless of whether one accepts the distinction between its first two phases ${ }^{7}$ or not $^{10}$. In the absence of data countering the previously published evidence that $\mathrm{Bj} / 13$ is likely a reworked deposit containing a mix of Middle and Upper Palaeolithic lithics, the claimed attribution to the Aurignacian and association with AMH is premature at best. $\mathrm{Bj} / 13$ cannot be used to draw any conclusions regarding the chronology of the appearance of AMHs in southern Iberia.

Lars Anderson ${ }^{1 \star}$, Natasha Reynolds ${ }^{2}$ and Nicolas Teyssandier ${ }^{1}$

${ }^{1}$ UMR 5608 TRACES, Université de Toulouse Jean Jaurès, Toulouse, France. ${ }^{2}$ UMR 5199 PACEA, Université de Bordeaux, Pessac, France. *e-mail:lars.anderson@univ-tlse2.fr

Published online: 15 April 2019 https://doi.org/10.1038/s41559-019-0885-3

References

1. Cortés-Sánchez, M. et al. Nat. Ecol. Evol. 3, 207-212 (2019).

2. Hublin, J.-J. Quat. Sci. Rev. 118, 194-210 (2015).

3. Cortés-Sánchez, M., Ferrer Palma, J. E., Marqués Merelo, I., Baldomero Navarro, A. \& Simón Vallejo, M. D. Mainake 29, 493-512 (2007).

4. Bergadà-Zapata, M.-M. \& Cortés-Sánchez, M. Cueva Bajondillo (Torremolinos, Málaga). Secuencia cronocultural y paleoambiental del Cuaternario reciente en la Bahía de Málaga (ed. CortésSánchez, M.) 93-138 (Centro de ediciones de la Diputación Provincial de Málaga, 2007)

5. Cortés-Sánchez, M. El Paleolítico Medio y Superior en el sector central de Andalucía (Córdoba y Málaga) (Monografías 22, Ministerio de Cultura, Secretarîa General Técnica, 2007).

6. Wood, R. E. et al. Proc. Natl Acad. Sci. USA 110, 2781-2786 (2013).

7. Teyssandier, N. \& Zilhão, J. J. Paleolit. Archaeol. 1, 107-138 (2018).

8. Le Brun-Ricalens, F., Brou, L. \& Pesesse, D. in Préhistoriques: Formes, Fonctionnements, Fonctions (eds. de Araújo Igreja, M., Bracco, J.-P. \& Le Brun-Ricalens, F.) 361-376 (ArchéoLogiques 2, Musée National d'Histoire et d'Art, 2006).

9. Bordes, J.-G. in Productions lamellaires attribuées à l'Aurignacien : Chaînes Opératoires et Perspectives Technoculturelles. XIVe congrès de l'UISPP, Liège 2-8 Septembre 2001 (eds. Le Brun-Ricalens, F., Bordes, J.-G. \& Bon, F.) 123-154 (ArchéoLogiques 1, Université de Liège, 2005).

10. Bataille, G., Tafelmeier, Y. \& Weniger, G. C. Quat. Int. 474, 3-29 (2018).

Competing interests

The authors declare no competing interests. 